\title{
ABSTENTION AND CERTIFICATION IN DIVERSITY SUITS: "PERFECTION OF MEANS AND CONFUSION OF GOALS"*
}

Pushing a rule to the limits of its logic is normally a game confined to the classroom. But courts, in a recent series of diversity cases, have manipulated the abstention doctrine to drive the rule in Erie R.R. v. Tompkins ${ }^{1}$ to its outermost bounds. As a consequence, the conflict between the diversity jurisdiction of the federal courts and the premises of Erie has sharpened. The dispute, in terms of abstention doctrine, concerns the range of circumstances in which the federal courts are required, or have discretion, to refer litigants to state courts for clarification of state law. Until recently that range has been narrowly circumscribed; but there is increasing evidence of a willingness on the part of federal courts exercising their diversity jurisdiction to abstain merely because the state law is unsettled. Because of the implications of this development for diversity jurisdiction, the desirability of such a substantial change in the complexion of federal jurisdiction must be evaluated in view of its potential for harsh effects upon the litigants as well as its significance for the federal judiciary. ${ }^{2}$ What Congress has consistently refused to do by legislation, ${ }^{\mathbf{3}}$ the courts may be busily achieving.

\section{The Early Doctrine}

The doctrine of abstention began humbly. ${ }^{4}$ As first formally announced by Mr. Justice Frankfurter in Railroad Comm'n v. Pullman Co., ${ }^{5}$ it seemed designed to permit a federal court to postpone and perhaps avoid decision of constitutional issues - in the particular case, the commission's authority to issue an order enforcing certain discriminatory hiring practices - in the hope that an unconstrued state statute would be so interpreted by the state court to obviate meeting the constitutional questions raised. This technique seemed harmonious with the "deeply rooted," though judge-made doctrine of avoiding

\footnotetext{
*"Perfection of means and confusion of goals seem - in my opinion - to characterize our age." - Albert Einstein in Out of My Later Years.

1. 304 U.S. 64 (1938).

2. See, e.g., England v. Louisiana State Bd. of Medical Examiners, 375 U.S. 411, 423-34 (1964) (Douglas, J., concurring), "Today we put federal jurisdiction in jeopardy." Id. at 427; Clay v. Sun Ins. Office Ltd., 363 U.S. 207, $227-28$ (1960) (Black, J., dissenting) ; Note, 111 U. PA. L. REv. 344, 346-48 (1963).

3. See note 44 infra.

4. See generally Wright, Federal Courts $\$ 52$ (1963) [hereinafter cited as Wright]; Barron \& Holtzoff, Federal. Practice and Procedure - Rules Edition $\$ 64$ (Wright ed. 1960) [hereinafter cited as BARRoN \& Holtzofr] ; Note, 59 Colum. L. REv. 749, 752766 (1959); Note, 108 U. PA. L. REv. 226, 227-34 (1959); Note, 69 Y YIE L.J. 643-48 (1960), which analyze the development of the doctrine. See also 1A Moore, Federal Practice If 0.203 [1], T 0.203[2] (2d ed. 1961) [hereinafter cited as Moore].

5. 312 U.S. 496 (1941). Pullman is generally considered to be the progenitor of the abstention doctrine.
} 
premature constitutional decisions. ${ }^{6}$ A second discrete basis for abstention was subsequently established: where under state regulatory schemes "expeditious and adequate" state review was provided to aggrieved parties, serious disruption of the complex state regulatory scheme by federal courts should be avoided. This rationale was first announced in Burford $v$. Sun Oil Co., where a state commission order for proration in Texas oil fields was challenged on equal protection grounds; there had been a long history of serious disruption of the complex state regulatory scheme by federal courts. The Buford rationale has been so broadened by subsequent cases, that now abstention is likely to be applied in any attempt to enjoin a state regulatory body in a federal court. ${ }^{8}$

From this narrow opening in the exercise of federal jurisdiction, pressure developed for abstention in diversity cases presenting difficult or uncertain questions of state law. Attempts to obtain this goal were firmly rebuffed in Meredith v. Winter Haven, ${ }^{9}$ the first time the question of abstention in such circumstances was presented to the Court. A Florida district court, presented with a "pure" question of state law in a diversity case, dismissed the plaintiff's case with prejudice. The Fifth Circuit reversed, instructing the court to enter a dismissal without prejudice to the right of plaintiff to proceed in state courts on the state law questions. The Supreme Court refused to allow this extension. In the majority's view, neither Erie nor the abstention doctrine, said to have vitality only "in exceptional cases," justified the circuit court's decision:

[D] ifficulties of ascertaining . . . state law ... do not in themselves afford a sufficient ground for a federal court to decline to exercise its jurisdiction to decide a case which is properly brought to it for a decision.

The diversity jurisdiction was not conferred for the benefit of the federal courts or to serve their convenience. Its purpose was generally to afford to suitors an opportunity ... to assert their rights in the federal rather than in the state courts. In the absence of some recognized public policy or defined principle guiding the exercise of the jurisdiction conferred, which would in exceptional cases warrant its non-exercise, it has

6. See Note, 69 Yale L.J. 643-44 (1960); Note, 108 U. PA. L. Rev. 226, 227-34 (1959); Note, 59 Colus. L. REv. 749, 752-57 (1959).

The policy can be traced at least as far back as Liverpool, N.Y. \& P.S.S. Co. v. Emigration Comm'rs, 113 U.S. 33, 39 (1885): The Court will not "anticipate a question of constitutional law in advance of the necessity of deciding it." See also Mr. Justice Brandeis' concurring opinion in Ashwander v. Tennessee Valley Authority, 297 U.S. 288, 346-47 (1936).

7. 319 U.S. 315 (1943). See Note, 69 Y ALE L.J. 643, 644-47 (1960); Note, 108 U. PA. L. Rev. 226, 230-31 (1959); Note, 59 Colum. L. Rev. 749, 757-62 (1959).

8. Cf. 1A MOore If 0.203[1], at 2103-09. See, e.g., Alabama Pub. Serv. Comm'n v. Southern Ry., 341 U.S. 341 (1951).

In addition to those cases falling within the Pullman or Burford rationale, there are a number of other situations referred to as abstention cases. For a discussion of these "miscellaneous" cases, see Note, 59 Colum. L. Rev. 749, 762-66; 1A MOoRE, it 0.203[2] (discussion of Thompson v. Magnolia Petroleum Co., 309 U.S. 478 [1940]). See also, Thompson v. Magnolia Petroleum Co., supra; Pennsylvania v. Williams, 294 U.S. 176 (1935), two leading examples.

9. 320 U.S. 228 (1943). 
from the first been deemed to be the duty of the federal courts, if their jurisdiction is properly invoked, to decide questions of state law whenever necessary to the rendition of a judgment. ...10

The language in Meredith expressed the harshness of the Court's reaction to a broader application of the abstention doctrine. It did not distinguish between situations where abstention would be mandatory and a perhaps broader group of situations where abstention might be granted in a court's discretion. ${ }^{11}$ Furthermore, there was no recognition of a difference in impact if the abstention was achieved by stay rather than dismissal. These distinctions, though they may be in fact quite formal, ${ }^{12}$ may have some appeal to a judge who does not want to appear to have ignored the Meredith mandate by giving up jurisdiction vested in him, yet wishes the freedom to abstain from decision on difficult questions of state law.

The doctrinal importance of these distinctions became apparent when the Supreme Court met its next wave of abstention cases. On a single decision day in June, 1959, the Supreme Court decided five abstention cases. ${ }^{13}$ Where previously abstention had been granted only in the context of equitable relief sought against a governmental body or agent, and had appeared to express a judicial duty, the Court for the first time approved abstention invoked as

10. 320 U.S. at 234 . See WRIGHT \& 52, at 175; 1A Moore f 0.203[2], at 2119-21.

11. The Supreme Court has often discussed abstention as though it were a unitary doctrine, without recognizing the possibility that in some cases abstention might be deemed mandatory and in others discretionary; or that in some cases it might be achieved by stay, and in others by dismissal. E.g., in Meredith v. Winter Haven, 320 U.S. 228 (1943), the Court does not seem to recognize these distinctions. Id. at 235-36. In Spector Motor Co. v. McLaughlin, 323 U.S. 101 (1944), the Court in ordering a district court to stay proceedings before it cites, inter alia, Burford v. Sun Oil, in which abstention was accomplished by dismissal. Id. at 105. In other cases the Court, while not articulating these distinctions, is more consistent in its citations. E.g., Harrison v. NAACP, 360 U.S. 167 , at 176-77 (1959). However, the attempt to develop the stay-dismissal distinction in Louisiana Power \& Light Co. v. City of Thibodaux, 360 U.S. 25, 38 (1959) is perhaps the first attempt of the Court to develop this notion. It may be suggested that the term "abstention" has invited such a gloss, that it describes the result of judicial action, rather than the factors calling forth action, and so invites indiscriminate use.

12. As the Supreme Court recently conceded, abstention implemented by staying federal court proceedings is likely to place the disposition of all questions in the hands of state courts. NAACP v. Button, 371 U.S. 415, 427-28 (1963). See England v. Louisiana State Bd. of Medical Examiners, 375 U.S. 411, 416-419 (1964); Note, Consequences of Abstention by A Federal Court, 73 Harv. L. REv. 1358, 1361-65 (1960). Similarly, a line of cases permitting abstention is likely to evolve without change into one requiring it. Cf. Burford v. Sun Oil Co., 319 U.S. 315 (1943), as extended by Alabama Pub. Serv. Comm'n v. Southern Ry. Co., 341 U.S. 341 (1951).

13. Martin v. Creasy, 360 U.S. 219 (1959) ; Harrison v. NAACP, 360 U.S. 167 (1959) ; Lassiter v. Northampton County Bd. of Elections, 360 U.S. 45 (1959) represented "the earlier pattern of decision, although each contains an aspect of special import in the application of the doctrine." Note, 108 U. PA. L. REv. 226, 235 (1959). The other two cases were County of Allegheny v. Frank Mashuda Co., 360 U.S. 185 (1959); and Louisiana Power \& Light Co. v. City of Thibodaux, 360 U.S. 25 (1959). See notes $15 \&$ 16 infra. 
a matter of discretion, undertaken in a common-law action, ${ }^{14}$ and involving what appeared to be little more than a difficult unclear question of state law. By finding distinctions which few had supposed to exist before, the Court called into serious question both the exceptional nature of the abstention doctrine and the Meredith affirmation of federal court duty in diversity cases to decide state law questions, however perplexing.

The result of the Court's work that day is not yet understood. In the two most significant cases, Louisiana Power \& Light Co. v. City of Thibodanx, ${ }^{15}$ and County of Allegheny v. Frank Mashuda Co. ${ }^{16}$ the Court seemed to pull in opposite directions. ${ }^{17} \mathrm{Mr}$. Justice Frankfurter's opinion for the Court in

14. Louisiana Power \& Light Co. v. City of Thibodaux, 360 U.S. 25 (1959), was the first case to apply the doctrine to an action at law, uncomplicated by the presence of factors which provided the rationale for abstention in the earlier cases, and was thus seen as a possible signal for the expansion of the doctrine. "[P] rior cases have been cases in equity. . ." 360 U.S. at 28. (Frankfurter, J.). WRTGHT $\S 52$, at 174 (1963). Compare Mr. Justice Frankfurter's attempt to minimize the significance of the "equity" origin of the doctrine by reference to the supposed "special and peculiar" nature of eminent domain proceedings, 360 U.S. at 28 , with the Pullman opinion, 312 U.S. at 500, which places heavy stress upon the significance of equity.

Nor was there any constitutional question which would justify Pullman-type abstention: The suggestion that federal constitutional questions lurk in the background is so patently frivolous that neither the District Court, the Court of Appeals, nor this Court consider it to be worthy of even passing reference.

360 U.S. 25, 33 (1959) (Brennan, J., dissenting).

15. 360 U. S. 25 (1959). The Thibodaux case involved a suit at law by the power company challenging a threatened eminent domain taking by the city. The City of Thibodaux filed a petition for expropriation in one of the Louisiana state courts, asserting the taking of certain power company property. The company, a Florida corporation, removed to the United States District Court for the Eastern District of Louisiana on the basis of diversity of citizenship. After a pre-trial hearing the federal judge, on his own motion, stayed the proceedings "until the Supreme Court of Louisiana has been afforded an opportunity to interpret" the relevant state statute. The Fifth Circuit reversed on appeal. Id. at 25-26. The city was acting under a previously unconstrued Louisiana statute ( $L_{\text {A }}$. Stat. ANN. tit. 19, \& 101 [1950]), the construction of which was placed in doubt by an opinion of the state attorney general. 360 U.S. at 30. The opinion appears at [1950-1952] Ops. LA. Atr'y GEN. 142. See City of Thibodaux v. Louisiana Power \& Light Co., 153 F. Supp. 515, 517 (E.D. La. 1957) ; Note, 69 Y ALE L.J. 643, 652-53 and accompanying foutnotes 63-66.

16. 360 U.S. 185 (1959). While condemnation proceedings were pending in a Pennsylvania state court, the property owners brought suit in a federal district court for a judgment of ouster, alleging that the taking was for private use and therefore contrary to state law. The district court, though acknowledging that its jurisdiction had been properly invoked, dismissed the suit. The Third Circuit reversed. There was no federal constitutional issue involved, and the relevant state law was clear - the case turning solely upon a factual determination: whether or not the proposed taking was for a public or private purpose. See id. at 187-90.

17. The two cases are extremely difficult to reconcile either with the earlier cases or with each other. See Note, 108 U. PA. L. REv. 226, 235 (1959). The majority in Thibodanx, note 15 supra, sought to justify that case on the special nature of eminent domain proceedings (360 U.S. at 26) and upon the distinction between Meredith v. Winter Haven, 
Thibodaux commended a district judge for referring to state courts the construction of an old eminent domain statute of doubtful meaning; Mr. Justice Brennan dissented for three justices. In Mashuda, Mr. Justice Brennan, now writing for the majority, affirmed a circuit court reversal of a district court decision dismissing a diversity action contesting eminent domain proceedings; Mr. Justice Frankfurter joined in a four-justice dissent by Mr. Justice Clark. The one judicial attempt at reconciliation, by Mr. Justice Stewart, ${ }^{18}$ portended a significant retreat from Meredith's broad injunction against abstaining for "mere" reasons of difficulty of state law. A federal district court, he suggested, could not, consistent with its duty in diversity cases, dismiss a case unless it fell within the exceptional categories suggested by cases like Burford, where considerations of harmonious federal-state relations were crucial; yet, where an important issue of state law was unclear, it was within the discretion of the federal judge sitting in diversity to stay the action before his court until state law questions had been resolved. ${ }^{19}$ The majority in Thibodaux relied, at least in part, on the same distinctions. Although the result in Meredith may be reconciled with Thibodaux by using such distinctions, the tenor of Meredith cannot, and the distinctions may prove frail reeds. ${ }^{20}$ The attempts to limit the role of the federal judiciary in diversity suits - which had been sharply rebuffed in Meredith without recognition of any distinctions between stay and dismissal, mandate or discretion - appear to have achieved substantial success in Thibodaux. Particularly when coupled with views he articulated in earlier dissenting opinions, ${ }^{21}$ Justice Frankfurter's Thibodanx opinion strongly suggested that an abandonment of Meredith $v$. Winter Haven was under way, and that abstention was to be available as a matter of discretion in all, or many, diversity cases in which relevant state law was unclear.

320 U.S. 228 (1934) (note 9 supra), and Thibodaux, that in one case abstention had been attempted by dismissal and, in the other, merely by stay. 360 U.S. at $27 \mathrm{n}$. 2 . The dissenters took sharp issue:

Since the Court suggests no adequate basis of distinction between the two cases, it should frankly announce that Meredith v. Winter Haven is overruled, for no other conclusion is reasonable.

360 U.S. at 38 n.4 (Brennan, J., dissenting).

Brennan also attacked the eminent domain distinction: "Surely eminent domain is no more mystically involved with 'sovereign prerogative' than ... a host of other governmental activities carried on by the States. ..." 360 U.S. at 37. The dissent's point was carried home by the majority opinion in Mashuda, which also involved a challenge to eminent domain proceedings. See the opinion of Brennan, J., for the Court in Mashnda, note 10 supra, 360 U.S. at 186-98, See WRIGHT \& 52, at 175.

18. Mr. Justice Stewart joined the majority in both Thibodaux and Mashuda. $\mathrm{He}$ wrote a concurring opinion in Thibodaux in which he suggests the basis of reconciliation. See 360 U.S. at 31.

19. Ibid.

20. See notes 11 and 12 supra.

21. See Justice Frankfurter's dissents in Sutton v. Lieb, 342 U.S. 402, 412 (1952); Propper v. Clark, 337 U.S. 472, 493 (1949); and cases cited in Thibodanx, 360 U.S. 25, 40-41. 


\section{The Fifth Circuit's Embellishments}

If that was the implication of Mr. Justice Frankfurter's opinion, it has recently borne fruit. Lower federal courts are showing increased proclivity toward "discretionary abstention" in diversity cases. "I was a member of the Court that launched Pullman and sent it on its way,"22 Mr. Justice Douglas noted during the current Term. "But if I had realized the creature it was to become, my doubts would have been far deeper than they were." 23 The most striking instances of this expansion are two recent Fifth Circuit cases, in which the circuit court has stayed proceedings before it until such time as uncertain state law might be ascertained in the appropriate state courts. Green v. American Tobacco Co., ${ }^{24}$ was a diversity action brought in the Florida District Court by a citizen of Florida seeking damages for wrongful death allegedly due to lung cancer caused by defendant's cigarettes. Florida law governed the rights and liabilities of the parties. There was no constitutional claim, no unconstrued statute, and no governmental party. In the absence of any controlling Florida decision, the circuit court was uncertain whether Florida common law would impose absolute liability on a cigarette manufacturer for breach of implied warranty. The court at first attempted to answer the question itself; on rehearing it reversed itself, in an unreasoned per curiam opinion, ${ }^{25}$ and certified the question to the Florida Supreme Court under that state's unique certification statute, ${ }^{26}$ which explicitly provides for certification of questions of state law from federal appellate courts to the highest state court. In the second and most recent case, United Services Life Ins. Co. v. Delaney, ${ }^{27}$ the circuit court abstained from decision in two cases governed by

22. England v. Louisiana State Bd. of Medical Examiners, 375 U.S. 411, 425 (1964).

23. Ibid.

24. 304.F.2d 70 (5th Cir. 1962), on subsequent proceedings, 325 F.2d 673 (1964), petition for cert. filed, 32 U.S.L. WEEK 3371 (U.S. April 21, 1964) (No. 961).

25. Id. at 85. The defendant had judgment in the District Court. On appeal, the Fifth Circuit affirmed by a divided panel. $304 \mathrm{~F} .2 \mathrm{~d}$ 70. "[O]n the morning of the argument, the Court [sua sponte] asked counsel to consider whether it should certify any issue to the Supreme Court of Florida ...." Further Supplemental Brief for Appellee Re Possible Certification to Florida Supreme Court, p, 1, Green v. American Tobacco Co., 304 F.2d 70 (5th Cir. 1962). On rehearing the court ordered the abstention. The per curiam order is at 304 F.2d 85. The Florida Supreme Court answered the certificate by opinion. 154 So. 2d 169 (Fla. Sup. Ct. 1963). The Fifth Circuit then reversed the original judgment and remanded the case for further proceedings in the District Court. Green v. American Tobacco Co., 325 F.2d 673 (5th Cir. 1963) (one judge dissenting in part).

While the Fifth Circuit did cite the United States Supreme Court's decision in Clay v. Sun Ins. Office Ltd., 363 U. S. 207 (1960), that citation was made without suggestion that the reasoning in Clay supported the abstention ordered in Green; rather it seemed more likely to have been cited merely to indicate that the Florida certification procedure had been previously invoked in Clay.

27. 328 F.2d 483 (5th Cir. 1964), petition for cert. filed sub nom. Paul Revere Life Ins. Co. v. First Nat'l Bank, 32 U.S.L. WeEk 3371 (U.S. Apri1 21, 1964) (No. 958). Similar attitudes can be sensed in other circuits. In A.F.L. Motors, Inc. v. Chrysler Motors Corp., 183 F. Supp. 56 (E.D. Wis. 1960) an injunction was sought against Chrysler to enjoin cancellation of the plaintiff's franchise in alleged violation of WIs. 
the Texas common law of insurance. Confused about the meaning of state decisions, a sharply divided court, sitting en banc, required the parties to seek not only declaratory judgment in the base-line Texas courts, but also review of that judgment in "a court of last resort." 28 Mere uncertainty about state decisional law ${ }^{29}$ - exactly what Meredith had stated to be irrelevant to the duties of federal judges to hear diversity cases - seems to have formed the sole reason for the Fifth Circuit's action. The four judge dissent in Delaney decried the departure from the duties outlined in Meredith, albeit the opinion hinted that the presence of a certification procedure like that of Florida might have stilled its voice. ${ }^{30} \mathrm{~A}$ concurrence by Judge Brown explicitly defended the decision to exercise the discretion to abstain on Erie grounds, asserting that responsibility was not abdicated, since by staying rather than dismissing the proceedings before it the court preserved its ultimate right to decide the case.

The adventurousness of the Fifth Circuit can be explained in terms of the omnipresent Erie. Once Pullman started abstention down the tracks, use of that technique could be justified, if not required, where the only "problem" of significance is the existence of unclear state law. As Mr. Justice Frankfurter said :

Stat. ANn. § 218.01(3) (a), subd. (15) \& (17) (1957). Defense counsel did not rely upon any constitutional ground so far as the motion before the court was concerned, though the court was obviously aware of, and considered, possible constitutional overtones. $183 \mathrm{~F}$. Supp. at 59 . However, these constitutional grounds seem to have been insubstantial. See Note, 1961 WIs. L. REv. 450, 453 n.19. The meaning of the statute was unclear and the court was "unable to get any help from the decisions" available. $183 \mathrm{~F}$. Supp. at 59-60. While the court did not order abstention, it clearly condoned the parties' desire for declaratory judgment. $I d$. at $60-61$. Apparently the only reason that a formal abstention order was not made was that:

... in its normal order this case will not be reached for trial on the merits for many months, giving the parties ample opportunity to endeavor to get an authoritative construction of the statute by the State courts.

$183 \mathrm{~F}$. Supp. at 61 . The court clearly stated that the case "is a situation in which the abstention doctrine could well be applied." Id. at 60 . Professor Wright has said: "The abstention ordered in A.F.L. Motors, Inc. v. Chrysler Motors Corp. . . . has no basis except that the diversity action presented a question of State law not yet decided by the State courts." WRIGHT $\$ 52$, at 175 n.42.

In another case the First Circuit has sanctioned abstention under circumstances similar to those in A.F.L. Motors and Green. See Commerce Oil Refining Corp. v. Miner, 303 F.2d 125 (1st Cir. 1962). Cf., the concurring opinion of Judge Friendly in Essex Universal Corp. v. Yates, 305 F.2d 572, 580 (2d Cir. 1962).

In a very recent Fifth Circuit case a Louisiana federal district judge's refusal to abstain as a matter of discretion was affirmed. American Universal Ins. Co. v. Chauvin, No. 20902, 5th Cir., March 12, 1964. See also Keidan v. Universal C.I.T. Credit Corp., No. 15349, 6th Cir., Feb. 13, 1964 (abstention denied).

28. 328 F.2d 483, 484-85 (5th Cir. 1964).

29. Neither the Pullman, supra, note 5, nor the Burford, supra note 7, rationale has any applicability to Green or Delaney, which were diversity suits between private parties. The only relevant precedent seems to be Meredith v. Winter Haven, supra note 10.

30. 328 F.2d 483, 485 (5th Cir. 1964). 
... no matter how seasoned the judgment of the district court may be, it cannot escape being a forecast rather than a determination. The last word on [state law] . . . belongs neither to us nor to the district court but to the [state supreme court]. . . . In this situation a federal court . . . is asked to decide an issue by making a tentative answer which may be displaced tomorrow by a state adjudication. ... The reign of law is hardly promoted if an unnecessary ruling of a federal court is thus supplanted by a controlling decision of a state court. ${ }^{31}$

Mr. Justice Frankfurter's notion fits comfortably with the view that Erie demands something closely approaching an identity of result, whether suit be brought in state or federal court. And it was frustration in the task of "forecasting" which seemed at the root of Judge Brown's concurrence in Delancy. His circuit, he indicated, had recently been "reversed" by state courts in a substantial number of cases.

[T | he "outcome determinative" test ... judge-fashioned to meet the needs of Erie, only few of which had emerged when Meredith ... was announced in 1943 ... recognizes that it is basically unfair for decision to turn on irrelevant accidents such as state citizenship, residence, geography, or the case being filed in one courthouse, rather than in one a block down the street.

If in like cases diverse results are unfair when precipitated by quasi procedural rules ... how much more unfair is it when diverse result flows from diverse holdings on substantive law. ${ }^{32}$

It is clear under Erie that where there is state authority which clearly answers the questions of state law involved, that law must prevail, and a federal court may make no independent determination. ${ }^{33}$ There are those who would take Erie no further; they say that at least so far as it was a constitutional decision, it was directed only to the Black \& White Taxicab ${ }^{34}$ fact situation, where a federal court simply ignored exsiting state decisional law. ${ }^{35}$ This narrow view would not extend Erie to the case where no state law exists, and draws strength from the Court's observation that Erie "is itself a precedent against any general ruling that cases properly in the federal courts that depend upon state law should have that issue submitted to state courts for decision."36 But, for the present, others who claim that Erie compels something more closely approaching an identity of result between state and federal courts seem to have carried the day. ${ }^{37}$ Of course, if Erie is read to compel as near an identity

31. Railroad Comm'n v. Pullman Co., 312 U.S. 496, 499-500.

32. 328 F.2d 483, 486 (5th Cir. 1964).

33. E.g., West v. American Telephone \& Telegraph Co., 311 U.S. 223 (1940).

34. Black \& White Taxicab \& Transfer Co. v. Brown \& Yellow Taxicab \& Transfer Co., 276 U.S. 518 (1928).

35. See Hart \& Wechsler, The Federal Courts and the Federal System 619 (1953) [hereafter cited as HART \& WeChSLER]. See also Parker, Bìlal Sovereignty and the Federal Courts, 51 Nw. U.L. Rev. 407, 411 (1956).

36. Propper v. Clark, 337 U.S. 472, 490-91 (1949).

37. Cf., Clark, Federal Procedural Reform and States' Rights; To a More Perfect Union, 40 Texas L. Rev. 211, 220 (1961) ; Smith, Blue Ridge and Beyond: A Byrd's-Eye View of Federalisn in Diversity Litigation, 36 Tulane L. Rev. 443, 466 (1962). 
of outcome as possible whether the suit be brought in state or federal courts, then abstention is surely a desirable end in cases in which there are unclear questions of state law, if the doctrine can be implemented in a manner consonant with other policies. For a state court may always reach a result inconsistent with a prior federal decision on the same question of state law, when that question finally comes before it. ${ }^{38}$ By referring state law questions which arise in federal courts to the state court for decision, such inconsistencies may be avoided.

\section{Green and Delaney at Trial Level - Rationales for Diversity Jurisdiction}

An examination of the bases of diversity jurisdiction suggests that abstention ought not to be extended at the district court level to the degree implied by Green and Delaney, for it is here, at the trial level, that most of the significant advantages of diversity seem to be grouped. The historic basis of diversity remains unclear, ${ }^{39}$ but it is generally suggested that the Framers of the Constitution included that jurisdiction out of a desire to protect out-of-state litigants from the feared bias of local courts and juries. ${ }^{40}$ Chief Justice Marshall, in an oft quoted dictum, stated that the Constitution provided for diversity jurisdiction because it "either entertains apprehensions ... or views with ... indulgence the possible fears and apprehensions of suitors. . ."41 Later, Justice Story, in another influential dictum, spolse to the same effect. ${ }^{42}$ Whether or not such prejudice ever existed is an unresolved question, as is whether it exists today. The promptness of congressional/action to create federal courts to sit in diversity cases, ${ }^{43}$ and the continued congressional resistance to pressures to end the jurisdictional grant suggest that the danger is at least felt

38. See the cases cited in Judge Brown's concurrence in Delaney, 328 F.2d 483, 48687 nn. 5-9 (5th Cir. 1964).

39. The origin of diversity jurisdiction has been the source of much significant legal writing. The classic articles are Warren, Nezv Light on the History of the Federal Judiciary Act of 1789, 37 HARv. L. REv. 49 (1923) ; Friendly, The Historic Basis of Diversity Jurisdiction, 41 HaRv. L. Rev. 483 (1928) ; Frankfurter, Distribution of Judicial Power Between United States and State Courts, 13 CoRNell L.Q. 499 (1928); Yntema and Jaffin, Prelininary Analysis of Concurrent Jurisdiction, 79 U. PA. L. REv. 869 (1931) (answer to Frankfurter's article); Frank, Historical Bases of the Federal Judicial System, 13 Law and Contemp. Prob. 3 (1948). See also the excellent collection of references and notes in HART \& WECHSLER 7-37 (constitutional origin), 892-97 (diversity jurisdiction).

40. Frank, supra note 39, at 22-28; Parker, Dual Sovereignty and the Federal Courts, 51 Nw. U.L. Rev. 407,409 (1956) ; Warren, stpra note 39, at 83. Cf. S. REP. No. 1830, 85th Cong., 2d Sess. 17-18 (1958); The FEDERalust, Nos. 80 and 81 (Hamilton). But see Friendly, supra note 39, at 492-98 (challenges "bias" argument). Compare Yntema \& Jaffin, supra note 39, at 873-76 (questioning Friendly's conclusion).

41. Bank of the United States v. Deveaux, 9 U.S. (5 Cranch) 61, 87 (1809).

42. Martin v. Hunter's Lessee, 14 U.S. (1 Wheat.) 304, 347 (1816). See Wright, The Abstention Doctrine Reconsidered, 37 TEXAs L. REv. 815 (1959).

43. One of the first measures enacted by the first Congress was The Judiciary Act of 1789,1 Stat. 73 (1789), which proved for diversity jurisdiction (1 Stat. 78) as authorized by Article III, $\S 2$ of the Constitution. The present statute is 28 U.S.C. $\S 1332$ (1958). 
to be a real one. ${ }^{44}$ The existence of a second, perhaps more sophisticated kind of bias against litigants denied a federal forum, has also been suggested as a modern basis for diversity. Whether or not juries are prejudiced against out-of-staters, they may, it is thought, be biased against certain classes of litigants, especially large corporations and financial institutions. The present guarantee of a federal forum, then, may be designed so to calm corporate and financial entities that they will establish business activity throughout the nation. ${ }^{45}$ Identification of other protections afforded by diversity is even more speculative, but also suggests the importance of preserving the federal trial forum. Commentators have suggested that, in addition to the guarantee of an unbiased trier of fact, protection against incompetent state judges and protection from judges chosen in a manner which might make them susceptible to extra-judicial pressures, ${ }^{46}$ might be a significant goal of diversity. Federal

44. Congress has from time to time altered the scope of diversity jurisdiction. HART \& WECHSLER 898-900. Most recently (in 1958), the jurisdictional amount was raised, along with certain other restrictions. 72 Stat. 415 (1958), 28 U.S.C. $\$ 1332$ (a) (jurisdictional amount), and (c) (corporations) (1958). There have been proposals to abolish the jurisdiction entirely. See Frankfurter, supra note 39. In the early 1930's the Senate Judiciary Committee reported bills for the abolition. S. REP. No. 530, 72 d Cong., 1st Sess. (1932) ; S. Rep. No. 691, 71st Cong., 2d Sess. (1930). The bills were not passed. The preliminary drafts of the American Law Institute's Study of the Diversity Jurisdiction indicates support for a sharp restriction of the jurisdiction. Frank, For Maintaining Diversity Jurisdiction, 73 YaLE L.J. 7 (1963) ; Kurland, The New Field Code - The A.L.I. Proposed Division of Jurisdiction Betzeen State and Federal Courts, 11 THe [UNIvERSITy of Chicago] Law School Record, No. 2, p. 11 (1963).

45. It is hard to be convinced that the great mobility which marks our present society would crumble if the diversity jurisdiction were curtailed or abolished. But see Parker, supra note 35, at 409-10, and materials cited therein; S. REP. No. 1830, 85th Cong., $2 d$ Sess. 19-20 (1958).

By extending diversity jurisdiction to suits between "citizens of different States" without attempt to restrict the right to invoke it to the out-of-state party, either in original or removal proceedings, Congress has discarded the notion that diversity is for the protection only of out-of-state litigants against the unknown, but presumed, vagaries of the state courts. The removal statute is 28 U.S.C. $\$ 1441$ (1958). See Wechsler, Federal Jurisdiction and The Revision of the Judicial Code, 13 LAw \& Contemp. Prob. 216, 236-37 (1947).

It is sometimes argued that the ends which the presumption of bias is intended to protect would be adequately preserved if the parties could obtain a federal forum upon a showing of actual bias, or if they had an ultimate right to raise that question on appeal or certiorari to the Supreme Court. See, e.g., Wechsler, supra, at 236. However, a requirement that actual bias be shown will present immediate problems of proof which may be impossible for the litigant to meet; even if possible, the burden in both time and finances may be so great as to discourage the attempted showing. The Framers of the Constitution seem to have rejected the adequacy of such a system. Cf., HART \& WECHSLER 17.

46. See, e.g., Kurland, note 44 supra, at 12 (quoting the unpublished A.L.I. study); S. REp. No. 1830, 85th Cong., 2d Sess. 18 (1958) ; Friendly, supra note 39, at 497-98. "[F]ederal judges appointed for life are more likely to enforce the constitutional rights of unpopular minorities than elected state judges." Douglas, J., England v. Louisiana State Bd. of Medical Examiners, 375 U.S. 411, 427 (1964). See id. at 427-28. 
procedures, to the extent not supplanted by Erie or mimicked by the states, ${ }^{47}$ the federal judge-jury relationship, ${ }^{48}$ and the benefits of a federally constituted record, ${ }^{49}$ may be an impetus to a litigant to choose the federal courthouse.

Although no one rationale for diversity may be persuasive, it is clear that litigants have continually found advantages to suit in federal court. Congress has certainly the power to deny a remedy for the presumptive bias, by abolishing or curtailing diversity jurisdiction. Once it has provided relief, however, - as it has since the First Judicary Act of 1789 - the queston is how far the courts may go in denying it. Relying largely upon another dictum of Chief Justice Marshall, ${ }^{\text {50 }}$ some have argued that the federal court's jurisdiction is mandatory, and when properly invoked must be exercised. Of course, this notion has been weakened by the earlier abstention cases, where the courts have assumed the power to curtail the federal jurisdiction in deference to the strong policy reasons of comity and avoidance of unnecessary constitutional decisions. ${ }^{51}$ But it is also arguable that these curtailments are consistent with congressional policy pre-dating Pullman, ${ }^{52}$ and manifested in the Johnson Act, ${ }^{53}$ the Tax Injunction Act, ${ }^{54}$ and the Three Judge District Court Act.0 While the Court has never relied upon the policy of these enactments, the underlying rationales of those acts is strikingly analogous to the reasoning in the early abstention cases. ${ }^{56}$ The Tax Injunction Act prohibits district courts

47. Post-Erie cases deny litigants many of the significant benefits of the federal procedure where state procedure is substantially different. See, e.g., Guaranty Trust Co. v. York, 326 U.S. 99 (1945) ; Ragan v. Merchants Transfer \& Warehouse Co., 337 U.S. 530 (1949); Woods v. Interstate Realty Co., 337 U.S. 535 (1949). And many states have adopted procedural reforms similar to the federal rules. See Frank, sutpra note 44, at 11 .

48. The judge-jury relationship may vary appreciably between the federal and state courts. Cf. Byrd v. Blue Ridge Elect. Coop., 356 U.S. 525, 537-38 (1958); Lumbermen's Mut. Cas. Co. v. Elbert, 348 U.S. 48, 52-53 (1954).

49. See England v. Louisiana State Bd. of Medical Examiners, 375 U.S. 411, 416-17 (1964) ; $i d$. at 436 (separate opinion of Douglas, J.). Other "reasons" for a litigant to prefer the federal forum exist. Locale of the respective courthouses, relative calendar congestion and the litigant's guess that the federal court will be less likely to depart from old state precedents may shape the decision. These ephemeral considerations may cut either way depending upon the litigant's individual situation.

50. Cohens v. Virginia, 19 U.S. (6 Wheat.) 264, 404 (1821). See, e.g., Louisiana Power \& Light Co. v. City of Thibodaux, 360 U.S. 25, 39 (1959) (Brennan, J., dissenting); Clay v. Sun Ins. Office Ltd., 363 U.S. 207, 223 n.19 (1960) (Black, J., dissenting), for recent instances where that argument has been used.

51. Cf., Meador, State Law and the Federal Judicial Power, 49 VA. L. Rev. 1082, 1095 (1963).

52. See Wright, supra note 42 , at 815 .

53. 48 Stat. 775 (1934), as amended, 28 U.S.C. $\$ 1342$ (1958). See HART \& WECHSLER 855-56.

54. 50 Stat. 738 (1937), as amended, 28 U.S.C. § 1341 (1958). See Hart \& WecrsLER 856-57.

55. 36 Stat. 557 (1910), as amended, 28 U.S.C. § 2281 (1958). See HarT \& WechsLER 846-55.

56. Cf. Hart \& Wechsler 847-57. See generally Wright $\$$ 47-51. 
from interfering with "the assessment, levy or collection of any tax under State law;"57 the Johnson Act similarly prohibits the district courts from interfering with "any order affecting rates chargeable by a public utility ... made by a State administrative agency. ...." Both provisions only apply where "a plain, speedy and efficient remedy may be had in the courts of such State." 59 Suits for injunctions to restrain enforcement of any state statutes upon the ground of unconstitutionality of such statute are required to be decided by a special three-judge district court, ${ }^{60}$ from whose judgment a direct appeal may be taken to the Supreme Court. ${ }^{61}$ The argument that jurisdiction is mandatory is far stronger for such cases as Green and Delaney, for Congress has seen fit to curtail federal jurisdiction only in limited areas. ${ }^{62}$

As a first proposition, then, the holding of Meredith, that a suit cannot be dismissed from federal court because state law which will be the basis of decision is unclear, should remain in force. Indeed, the Supreme Court has itself remained careful not to question it. ${ }^{63}$ Federal court action which, although denominated a stay, has all the effects of dismissal, ${ }^{64}$ would also seem to be an improper renunciation of jurisdiction. And if abstention such as occurred in Delaney were essayed at the trial court level, it can hardly be doubted that an effective dismissal would occur. The state courts to which the parties were referred would likely wish to engage in full-blown fact-finding themselves, and litigants faced at such an early stage with the prospect of two suits where they had expected but one might often confine their attentions to the state litigation. The advantages supposed to arise from use of diversity jurisdiction are most relevant at the trial stage, where judicial action which inevitably discourages parties from availing themselves of a federal right persistently offered them by Congress does not seem justified by the rewards to be gained from an authoritative statement of state law.

\section{Green and Delaney at Appellate Level}

When abstention is permitted at the appellate court level, on the grounds of unclear state law, litigants are likely to be deprived of only minor benefits accruing from diversity jurisdiction. In such cases abstention would be im-

57. 28 U.S.C. $\$ 1341$ (1958).

58. 28 U.S.C. $\$ 1342$ (1958).

59. Compare 28 U.S.C. $\$ 1341$ (1958) with 28 U.S.C. § 1342 (1958).

60. 28 U.S.C. $\& 2281$ (1958).

61. 28 U.S.C. $\$ 1253$ (1958).

62. Congress has consistently refused to substantially affect the availability of diversity jurisdiction. See note 44 supra. See also S. REP. No. 1830, 85th Cong., 2d Sess. 18 (1958).

63. Meredith v. Winter Haven, 320 U.S. 228 (1943) was cited approvingly by the Court in Thibodaux, 360 U.S. at 27 and more recently in McNesse v. Board of Educ., 373 U.S. 668, 673 n.5 (1963) (dictum).

64. See, e.g., NAACP v. Button, 371 U.S. $415,427-28$ (1963). See also and compare England v. Louisiana State Bd. of Medical Examiners, 375 U.S. 411, 414-19 (1964) (Brennan, J., for the Court), with id., at 426-29 (Douglas, J., concurring in the result). See Note, 73 Harv. L. Rev. 1358, 1361-68 (1960); Note, 64 Colum. L. Rev. 766 (1964). 
plemented by the circuit court staying its appellate jurisdiction to await the resolution of state law questions by the appropriate state courts. This would come only after there had been a full federal trial on the merits. To some extent there would also have been a fairly complete federal appeal. No judge's decision will be vacated, no jury verdict will be upset because of any "error" committed by the district judge's failure to abstain. The role of the state court would be to simply declare "authoritatively" what the state law is. It is not doubted that under Erie a federal court must follow state law as the rule of decision. Save for considerations of cost and delay which abstention may add to a litigation, it may well be thought that it is irrelevant to the litigants that the judges may ascertain state law by one process or another - by consulting with their law clerks or by abstaining in favor of their state counterparts.

But abstention imposes an additional burden, and one that is unwanted by at least one of the parties. The litigants will already have made a substantial investment in their federal cause of action at the trial level. For them the doctrine has the effect of "making two law suits grow, where only one grew before," with concommitant expense and delay. ${ }^{05}$ Indeed the possibility of imposing such delay and/or expense upon his adversary may be the principal reason behind a litigant's espousal of the doctrine. ${ }^{66}$ To the individual litigant, the possibility of ultimate disparity between state and federal decision may

65. See note 83 infra. The federal forum in a diversity suit will always be the choice of either the plaintiff who invoked federal jurisdiction under 28 U.S.C. \$ 1331 (1958) or of the defendant who secured removal from a state court under 28 U.S.C. $\S 1441$ (1958).

66. It is likely that this was a factor in Thibodantx, note 15 supra. The petitioner removed to the federal district court. When that court abstained on its own motion, the defendant city appealed and the district judge was reversed. On certiorari to the Supreme Court it was the petitioner power company, which had originally opted for the federal forum by removing, that was now demanding referral to the state courts. It is curious that the governmental party did not oppose a federal determination of the relevant unconstrued state statutes. The effect of Thibodantx was to give the power company "the best of all possible worlds."

[T] he doctrine of abstention ... can become [an effective tactic] in the hands of a defendant anxious to postpone decision.... In a removable case to which the doctrine . . . is held applicable there is nothing the plaintiff can do to avoid considerable delay, additional labor and expense. For if he files his claim in state court, it can be removed, and stayed, and he will be compelled to initiate a new action in the state court, prosecute it there through appeal, then return to the Federal court for further proceedings, and probably review on appeal. Filing initially in the Federal court saves him little, since he must still start over in the state court, and eventually return to the Federal forum.

.. . This "judicial sanction of professional astuteness" can but encourage "the natural selfishness of litigants to exploit the law's weaknesses." [Quoting Mr. Justice Frankfurter's concurring opinion in Lumbermen's Mut. Cas. Co. v. Elbert, 348 U.S. 48, 57 (1954); the words were there used in a different context.]

Respondent's Petition for Rehearing, pp. 14-15, Louisiana Power \& Light Co. v. City of Thibodaux, 360 U.S. 25 (1959).: (Footnotes omitted.) 
not be of overriding importance - he likely has little concern with the aesthetics of the legal order and, by hypothesis, knows the law to be presently uncertain when he begins his suit. Naturally, every litigant seeks and desires a favorable decision in any suit to which he is a party. At least, however, litigants do have the right to an impartial, uniform and prompt decision by judges doing their best, not their worst. ${ }^{67}$ And they receive that exactly when non-abstaining federal judges decide their claims. The litigants have had their "day in court," and their claims are resolved. Such a decision in the present may be more highly valued than some "more perfect" decision in the future. ${ }^{68}$ If a litigant chooses to bring suit in a federal court, for whatever reasons may have been persuasive to him, and a complete denial of federal jurisdiction is not called for by considerations of constitutional policy or comity, consigning him to the half-way house of abstention may, from his perspective, involve a senseless and intolerable burden.

The decision to abstain or not, however, may have an impact upon other participants in the legal system than the parties to a particular litigation. One serious effect which might be thought to flow from the possibility of divergent decisions is the disruption of legitimate private ordering. ${ }^{60}$ In the interim between the rendering of a federal decision and ąn "authoritative" state decision, persons entitled to reliance may feel prior arrangements to be in doubt or may base new arrangements on the federal statement, albeit the "true" state rule may be quite different once the state court is given the opportunity to declare it. ${ }^{70}$ Another possibility is a more casual attitude on the part of federal judges, who may lose hope of being able to render acceptable opinions and, however unconsciously, begin to direct their fullest efforts to other questions, where they may bear a more continuing responsibility. In a circuit such as the Fifth, where through repeated failures to divine state trends, ${ }^{71}$ the judges seem to have become infected with a strong disinclination to grapple with

67. Cf. Corbin, The Laws of the Several States, 50 YALE L.J. 762 (1941).

68. Clark, State Law in the Federal Courts: The Brooding Omnipresence of Erie v. Tompkins, 55 YaLE L.J. 267, at 293. In none of the four cases in which the Florida certification device has been used, have the litigants asked the court to abstain. Dresner v. City of Tallahassee, 375 U.S. 136 (1963); Aldrich v. Aldrich, 375 U.S. 75 and 249 (1963) ; Clay v. Sun Ins. Office Ltd., 363 U.S. 207, 212 (1960); Green v. American Tobacco Co., Further Supplemental Brief for Appellee Re Possible Certification to Florida Supreme Court, pp. 1-2; cf., 304 F.2d 70, 85-6 (1962).

69. Cf., A.F.L. Motors, Inc. v. Chrysler Motors Corp., 183 F. Supp. 56 (E.D. Wis. 1960) where the District Judge said: "No attorney could conscientiously advise a client" under the existing circumstances of uncertain state law. Id. at 59-60. See note 27 supra for background on A.F.L. Motors case.

70. Some undesirable forum shopping may occur during the interim between the federal and state decisions caused by litigants jockeying for position in the forum most likely to follow a desired rule. But, this very effect may have the result of bringing the question before a state court at the earliest possible date.

71. Cf. United Services Life Ins. Co. v. Delaney, 328 F.2d 483, 486-87 nn. 5-9 (5th Cir. 1964) (concurring opinior of Brown, J.). 
testy state law questions, litigants may appear to be better served by a state court than a federal.

The weight to be attached to the possibility of disparities can be too easily exaggerated. It is surely true that state courts may "reverse" federal determinations of state law. However, in many instances, there will be no difference in the respective decisions. ${ }^{72}$ State courts are likely to reach the same results as federal courts have previously ${ }^{73}$ counsel responsible for private ordering may be expected to appreciate the stature of a federal decision under Erie. and to treat the state law as still unsettled. And apparent dissimilarities may be illusory, if accounted for by differences in the factual patterns presented. Further, it should be remembered that, while in theory abstention will produce an "authoritative" answer not liable to "be displaced tomorrow by a state adjudication," in fact, abstention does not assure this to be so. Parties remitted to state courts for declaratory judgment, for example, may, for various reasons, choose not to take appeals from the initial state decision to the highest state court; they may not even appeal to an intermediate appellate court. In such a case, while the decision obtained is clearly the law of the case in the federal court, under current Erie dogma it is clear that the state court decision may not be controlling upon a federal or state court in another case. ${ }^{74}$ The Fifth Circuit, apparently in an effort to remedy this situation, ordered the parties in Delaney to pursue their declaratory judgment proceedings to the highest available state court ; but this authority was purchased only at the expense of considerable additional delay and cost to the litigants. It is surely open to question whether individual litigants should be made to bear the costs - in time and expense - of correcting the imperfections and inadequacies of the legal system - imperfections and inadequacies with which the non-institutional litigant may have no concern.

The existence of what may ultimately come to be a lone federal precedent on a question of state law may even have advantages to the system. It may provide limited experience with a rule of law, and may provoke academic or judicial commentary on the proposed rule of law. Thus, when ultimately ćalled upon to make its "authoritative adjudication," the state court will have additional and valuable materials at hand. Indeed, the state court may ultimately reach a result inconsistent with the earlier federal case only because this dialogue pointed out the pitfalls of the federal decision. ${ }^{75}$

72. E.g., the especially interesting case of Daily v. Parker, 152 F.2d 174 (7th Cir. 1945), followed in Johnson v. Luhman, 330 Ill. App. 598, 71 N.E. 2d 810 (1947).

73. See text accompanying note 75 infra.

74. See King v. Order of United Commercial Travelers of America, 333 U.S. 153 (1948). But cf., Fidelity Union Trust Co. v. Field, 311 U.S. 169 (1940) (criticized sharply by Corbin, supra note 67). See 1A MOORE If 0.307[2], at 3305-10.

75. Federal participation may induce a certain degree of nation-wide uniformity of state law. Cf. HART \& WeChsLer 89 (Item 4). See Yntema \& Jaffin, supra note 39, at $881 \mathrm{n} .23$. In this extensive footnote, the authors question whether there was a development of uniform national law arising from Swift v. Tyson, 41 U.S. (16 Pet.) 1 (1842). Federal courts are said to play a substantial role "as leaders in the movement for the improvement 
That the new use of the abstention doctrine has been developed in the Fifth Circuit, where state-federal relations are strained, suggests that it may have both origins and merits in the realm of "federalism."7wa Just as the overruling of Swift $v$. Tyson ${ }^{76}$ may in some sense have been a response to state sensitivity to the vigorous growth of federal regulatory activity, it may be postulated that the Fifth Circuit is in some way, however unconscious, compensating the Southern states for its vigorous advances against their traditional social fabric. To the extent that past history has shown that court to be inaccurate in forecasting state law developments, ${ }^{77}$ use of abstention would avoid exacerbation which must accompany each "overruling." The feeling that the federal court was "cooperating" in the search for state law rather than seeking to impose its will upon the state might even make state judges more receptive to federal views, when federal questions were before state judiciaries.

The argument for avoiding disparity, if carried to its logical conclusion and distinctions do not appear which would enable courts to hold the line short of that conclusion - would sap federal judges of any vital role in diversity cases. The Erie case was widely criticized for depriving federal judges of their traditional law declaring functions $;^{78}$ in the absence of the abstention of the administration of justice." Clark, Federal Procedural Reform and States' Rights, 40 Texas L. REv. 211, 213 (1961).

For the great virtue of the Federal system is that each state becomes ... a laboratory in which [each of] the other ... States can see how theories actually work when put into practice. No one state . . can injure the nation as a whole, and the follies of one state are almost certain to teach wisdom to the others. . . .

Walter Lippman, New York Herald Tribune, June 2, 1936, quoted in THuRMond ARNold, The FolkLoRE of CAPITALISM 94 (1937). Arnold sharply disagrees with this notion. See id. at 93-96.

Cf., Wechsler, The Political Safeguards of Federalisn, 54 Colvm L. Rev. 543-46 (1954). See Hart, The Relations Between State and Federal Law, 54 Couum. L. Rev. 489, 492 (1954). Professor Hart has stated:

Constitutional impediments to centralized direction, in those matters in which there is no compelling need for national action, appear as safeguards against impairments of the viability of the social mechanism as a whole. The resulting disparities in the formal law of different states are notable chiefly as reflections of a necessary independence and even competition in the wise guidance of social affairs ... [by the states].

Id. at $490-91$.

Cf., Mr. Justice Holmes' eloquent dissent in Black \& White Taxicab \& Transfer Co. v. Brown \& Yellow Taxicab \& Transfer Co., 276 U.S. 518, 532-36 (1928).

75a. The Fifth Circuit is also probably the largest and most overworked of the courts of appeal. Lewis, Choosing a Judge May Tax Johnson, N.Y. Times, April 6, 1964, p. 21, col. 4 (City ed.).

76. 41 U.S. (16 Pet.) 1 (1842).

77. See United Services Life Ins. Co. v. Delaney, 328 F.2d 483, 486-87 nn. 5-9 (5th Cir. 1964) (concurring opinion of Brown, J.).

78. See, e.g., Corbin, The Lazes of the Several States, 50 YALE L.J. 762 (1941); Clark, Statc Law in the Federal Courts: The Brooding Omnipresence of Erie v. Tompkitis, 55 Y ALE L.J. 267 (1946). 
doctrine, however, the Erie doctrine does not bind the creative federal judge to the extent that its critics pretend. Among other duties, it leaves to federal judges the function of declaring state law where there was no discernible answer to the question in pronouncements of the state institutions. Abstention, if applied across the board, in cases of the Green and Delaney variety, would mean that federal judges not only must obediently follow well-found state precedents, ${ }^{79}$ but that they must farm out to the state judiciary responsibility for the decision of questions of unsettled state law. Accordingly, opponents of abstention can mount a convincing argument that federal judges would be reduced to little more than sterile monitors shuttling traffic between a dual system of courts at appropriate stages of the litigation. Litigants would, again, be discouraged from invoking the diversity jurisdiction as judges felt themselves under greater pressure to invoke the doctrine, and apparent congressional intent would be, to that extent, disserved.

\section{The Uses of Certification}

An assessment of the advantages and disadvantages occasioned by the use of abstention in cases of unclear state law does not lead to a clear preponderance, for many of the factors discussed are extraordinarily elusive. In such a situation, it is tempting to take the easy road, stating that the more definite factors - cost to litigants and incursion upon the diversity function - force the conclusion that the Fifth Circuit's use of the doctrine was improper. It may not be entirely cynical to view abstention as a "legal research luxury," of no appeal to the litigants to any given suit, and of but questionable value to the legal system as a whole. Certainly, in view of the sometime harsh effects which the doctrine's use will impose upon litigants and other participants in the legal process, the price which must be paid for abstention is higher than the "easy" adoption of the device by the Fifth Circuit would suggest. ${ }^{81}$ However, if some of these unpalatable results can be substantially mitigated, the case against abstention may not be so clear. Prior discussion suggests that these effects become more acute as use of the doctrine becomes more general, and as the state procedures to which litigantsmust repair to obtain the "authoritative" pronouncement on state law become more intricate. If one is convinced that the doctrine does provide some advantages to the system, then a sparing use, in situations which present the possibility of a "plain, speedy and efficient" state procedure for the ascertainment of state law, may well be seen to provide circumstances suitable for invocation of the doctrine.

79. Cf., Professor Corbin's sharp criticism of this alleged stultification of the federal judiciary brought about by Erie, Corbin, supra note 78, at 762 .

80. The phrase is Mr. Justice Douglas'. See England v. Louisiana State Bd. of Medical Examiners, 375 U.S. 411, 425 (1964).

81. See note 83 infra. Mr. Justice Douglas has suggested that in some cases the consequence of abstention "seems like an unnecessary price to pay for our federalism." England v. Louisiana State Bd. of Medical Examiners, 375 U.S. 411, 426 (1964). 
As a first step in obtaining such a tempered use of abstention, it seems possible to give some content to the criterion "unclear state law." A hierarchy of values may be helpful. ${ }^{82}$ An unconstrued state constitutional provision, being the fundamental law of the State, seems to be entitled to the greatest respect by the federal courts. State statutes, being the expressed will of the legislature, would seem to be almost equally deserving of respect. Thus, a coordinate branch of the same governmental system responsible for the questioned enactment ought to be given the opportunity to construe it as broadly as it wished, so as to squarely present any issue which a federal court would be tempted to avoid by a narrower construction. State courts may be significantly more expert than federal courts in the understanding and construction of state legislative intent. Questions of state common law appear to be more troublesome; although state court pronouncements are more authoritative, there is no reason to expect that they will be rendered with significantly greater skill than would be the case in the federal courts. Yet it may be possible to identify the significant areas of state concern - areas closely allied with statutory regulation and hence of greater delicacy. Other questions may be deserving of state determination because they deal with an area of law which is undergoing significant development, or because the law of other jurisdictions is in sharp conflict, suggesting the need for a fundamental policy choice. Indeed, the question in Green, relating to the liability of cigarette companies for injuries from lung cancer, may be just such an issue. If the federal judge is convinced that the question posed to him is close to a matter of central and continuing state concern, then, he may be justified in invoking the doctrine.

Since at the appellate level the principal cost of abstention is in expense and delay to litigants, the federal court could properly be far more liberal in abstaining where, in the particular case, these factors were demonstrably unimportant, or likely to be held in check by the procedures available in state courts. Where implemented by means of declaratory judgment, abstention has shown itself to be a slow and costly process for the litigants, often requiring them to proceed through the multiple tiers of two independent judicial systems. ${ }^{83}$ The Florida certification device, ${ }^{84}$ on the other hand, allows liti-

82. Cf. Wright, supra note 42 , at 826 .

83. Delay is a frequent concommitant of abstention. E.g., see the discussion of the long trek through the courts of Government and Civic Employees Organizing Committee, CIO v. Windsor, 353 U.S. 364 (1957) in BarRoN \& HoxtzofF $\S 64$, at 343; Wright, stipra note 42 , at 817 .

Leiter Minerals, Inc. v. United States began in August, 1953. In 1957, the Supreme Court ordered abstention. 352 U.S. 220 (1957). Subsequently, Louisiana courts rendered three opinions. The case has just returned to the Fifth Circuit. No. 19963, 5th Cir., March 3, 1964. See also Note, 111 U. PA. L. REv. 344, 346-48 (1963) ; Mr. Justice Douglas's separate opinion in United Gas Pipe Iine Co. v. Ideal Cement Co., 369 U.S. 134, 136 (unnumbered footnote) (1962) (per curiam). Mr. Justice -Douglas's dissent in Clay v. Sun Ins. Office Itd., 363 U.S. 207, 228 (1960) suggested:

Some litigants have long purses. Many, however, can hardly afford one lawsuit, let alone two. Shuttling the parties between state and federal tribunals is a sure way of defeating the ends of justice. The pursuit of justice is not arr academic 
gants to skirt the lower state courts entirely and to obtain a judgment directly from the highest state court in answer to propounded questions of state law, a procedure which may result in considerable savings of time and expense. ${ }^{85}$ It assures that the state court resolution is, in Justice Frankfurter's word, "authoritative," because it is rendered by the highest state court - a quality which declaratory judgment does not necessarily produce. Certification also has the benefit of clearly preserving the federal fact-finder and of closely limiting the state court consideration to the matters of concern to the federal court. Although in the few cases to date in which the Florida process has been used the questions have been quite properly framed in a factual setting, they were sent up on a federal record, ${ }^{86}$ with the litigants briefing and arguing

exercise. There are no [private charitable] foundations to finance the resolution of nice state law questions involved in federal court litigation.

See also, Clark, Federal Procedural Reform and States' Rights, 40 TEx. L. Rev. 211, 221 (1961) ; separate opinion of Mr. Justice Douglas in England v. Louisiana State Bd. of Medical Examiners, 375 U.S. 411, 425-6 (1964). And compare, RabezAIs. Complete Works 445-453 (Mod. Lib. ed. [Le Ciercq trans.]).

84. Fla. Stat. ANN. § 25.031 (1961). Great Britain has long had a comparable statute (Foreign Law Ascertainment Act, 1861, 24 \& 25 VICr., c. 11). It has apparently met with little success. Cf., Dicey, Conflicr of Laws 1115 (Morris' 7th ed. 1958). In this country the Florida statute is unique. It was used for the first time, at the urging of the Supreme Court, in connection with Clay v. Sun Ins. Office Ltd., 363 U.S. 207, 212 (1960). The Court has sanctioned the use of $\S 25.031$ in several subsequent cases, seemingly well pleased with its operation. See Dresner v. City of Tallahassee, Fla., 375 U.S. 136 (1963) ; Aldrich v. Aldrich, 375 U.S. 75 and 249 (1963). See also separate opinion of Douglas, J., in England v. Louisiana State Bd. of Medical Examiners, 375 U.S. 411, 433-34 (1964). See generally Vestal, The Certified Question of Law, 36 Iowa L. Rev. 629 (1951) (certification generally); Note, 111 U. PA. L. Rev. 344 (1963).

85. The certification device has not resulted in speedy resolution in either of the two cases which have been sent to the Florida Supreme Court, and which that court has answered. In Clay v. Sun Ins. Office Ltd., 363 U.S. 207 (1960) recourse to certification was ordered June 13,1960. On remand, the Fifth Circuit certified questions to the Florida court on August 12, 1960; the Florida court's opinion is dated October 18, 1961 (133 So. 2d 735). The Fifth Circuit's decision, 319 F.2d 505, was dated June 19, 1963, and the case is again before the Supreme Court at the current term on certiorari. Cert. granted, 375 U.S. 929 (1963). The Clay suit was originally commenced on May 20, 1957. 319 F.2d 505, 507 (5th Cir. 1963).

In Green v. American Tobacco Co., 304 F.2d 70 (5th Cir. 1962) abstention was ordered on June 20,1962. A certificate was issued on August 8,1962. The Florida court's opinion (154 So. 2d 169) was decided on June 5, 1963 and received by the Fifth Circuit June 24, 1963. The Fifth Circuit opinion, 325 F.2d 673, is dated December 11, 1963. However, it would seem that the process could be significantly speeded up by cooperation between the state and federal courts. Obviously the cost of certification is less than obtaining declaratory judgment. Cf., Note, 111 U. PA. L. REv. 344, 348 (1963).

86. Fla. App. R. 4.6 promulgated under Fla. Stat. Ann. \$ 25.031 (1961) provides:

Rule 4.6(d) The certificate . . shall contain . . . a statement of facts showing the nature of the cause and the circumstances out of which the questions or propositions of law arise....

Rule 4.6(e) ... The Supreme Court may, in its discretion require ... all or any portion of the record before the federal court to be filed with said certificate... See In re Florida Appellate Rules, 127 So. 2d 444 (Fla. Sup. Ct. 1961) for the complete text of Rule 4.6. The rules are also found in Volume 31 of FrA. Stat. Ann. (1962 Supp.). 
only questions of law in the state court. ${ }^{87}$ Given the speed, authority and economy possible using certification procedures, abstention under these procedures could tolerably range a far wider scale of state law questions than abstention implemented by declaratory judgment.

One question which might be raised with regard to the certification procedure is whether it ought to be broadened, so as to be made available to federal district courts. The earlier abstention cases clearly allowed these courts to order abstention in proper cases. ${ }^{88}$ Yet, though it has been suggested that a district court could request its circuit court to make the certification for it, ${ }^{89}$ the present Florida certification statute provides that only federal appellate courts may certify questions of Florida law to that state's Supreme Court. ${ }^{80}$ Certification, it can be argued, derives much of its attractiveness from its potential for expedient resolution of state law questions by the highest state court; this potential for speed is offset if a trial court may not abstain via the certification device. For example, a party may learn in answer to a certificate sent after an appeal, that the original complaint failed to state a cause of action or that the federal trial court's resolution of a state law question was inaccurate, although it was apparent in pre-trial stages that a question needed to be resolved by the state court."1 On balance, however, it would seem that there is more wisdom in restricting the device's availability to the appellate level. For federal policy, the principal consideration is preservation of the federal fact finding forum for the party who has opted for diversity. Abstention at such an early stage seems to threaten his ability to shape his presentation of

87. Present Florida rules require that the parties file briefs. FLA. App. R. 4.6(g) (Supp. 1962). The court may grant oral argument. FLA. ApP. R. 4.6(h) (Supp. 1962).

88. E.g., Louisiana Power \& Light Co. v. City of Thibodaux, 360 U.S. 25 (1959).

89. Kaplan, Certification of Questions from Federal Appellate Courts to the Florida Supreme Court and Its Impact on The Abstention Doctrine, 16 U. MIAMI L. Rev. 413, 431 (1962) ; Note, 73 Harv. L. Rev. 1358, 1368 (1960) ; Note, 111 U. PA. L. Rev. 344, 357-58 (1963).

- Such a possibility is by no means clear from the statute. Under Fla. Stat. Ann. $\S 25.031$ (1961) a federal appellate court may certify "questions or propositions of the laws of this state, which are determinative of the . . cause" if they are "involved in any procecding before it." (Text of the law transposed, and emphasis added.)

90. Fla. Stat. AnN. $\S 25.031$ (1961). Apparently the draftsmen of $\S 25.031$ had no particular reason for restricting the power to certify to appellate courts, other than to curtail the volume of certificates.

When the original bill was drafted ... its use was limited to the federal appellate courts largely because ... we did not want too many certificates coming in to the Supreme Court that might clutter up its docket. We know of no legal reason why Section 25.031 might not be made available to the lower federal courts. The use of said section by lower federal courts seems to be more a matter of policy than a legal one.

Letter from Hon. Fred M. Burns, Assistant Attorney General of Florida, December 19, 1963, to the Yale Lazo Journal, on file in Yale Law Library. Mr. Burns drafted the statute.

91. See A.F.L. Motors, Inc. v. Chrysler Motors Corp., 183 F. Supp. 56, 61 (E.D. Wis. 1960). 
legal issues in federal court: State policy is remarkably similar; the Supreme Court of the state can be expected to prefer questions accompanied by a full factual record to abstractions smacking of "advisory opinions." A constitutional provision similar to the federal "case or' controversy" clause might render such a preference mandatory. ${ }^{92}$ Moreover, all the policies usually associated with ripeness and finality seem to apply. Questions which appear at pre-trial and early trial stages may disappear by the time a verdict has been returned. In a case like Green, the question of Florida law certified could have been rendered moot by a jury finding that there was no causal relationship between smoking and the plaintiff's cancer. In other cases, a question of state law might not appear until the final stages of litigation, and if certification had been allowed at an early stage, multiple certifications could arise causing considerable delay. ${ }^{93}$ Restricting certification to appellate courts will also prevent an inordinate number of cases flooding the state court on certificates. ${ }^{94}$ Although the Florida statute, which is permissive rather than mandatory, allows the state court wide discretion in deciding whether or not to answer a certificate, ${ }^{95}$ in practice it may well be considered impolitic for a state court to refuse to take the opportunity to answer the propounded questions. ${ }^{96}$ Moreover, restricting the right of federal courts to certify may provide an inherent selectivity; since only appeals courts may certify, only those cases which are deemed significant to the parties will be eligible for abstention via certification.

It appears that the certification device is susceptible of perfection to a degree that will substantially eliminate delay and, to a large extent, eradicate the costliness of declaratory judgment. If abstention is to be expanded or even if it is to be limited to its present scope, it seems highly desirable that certification procedures be made generally available. ${ }^{97}$ This can, of course, be achieved

92. For a discussion of the "case and controversy" and related problems see Note, 111 U. PA. L. REV. 344, 351-57 (1963).

93. In some cases abstention at pre-trial stages may be appropriate. The existence of a constitutional question in the Pulman-type case appeared in the pleadings. The pleadings would also clearly establish that the suit is one to enjoin a state administrative agency - the touchstone of the Burford-type abstention.

94. See note 90 supra (Letter of Hori. Fred M. Burns).

95. Fla. Stat. ANn. § 25.031 (1961). See also Fla. App. R. 4.61 (a) (Supp. 1962). The state court may not desire to answer the question; and possibly could avoid doing so in a purely intra-system case if it had discretionary powers of review. See, Vestal, supra note 84 , at 646-47.

Presumably the certification statute does not prevent a federal district court from directing the parties to use the declaratory judgment method of effectuating an abstention order issued by it, or in a case where the Florida Supreme Court declines to answer the certificate. Florida has such a procedure. Fla. Stat. ANN. $\S \S 87.01-13$ (Supp. 1962).

96. Note the open expression of gratitude by the Fifth Circuit to the Florida Supreme Court. Green v. American Tobacco Co., 325 F:2d 673, 674 (5th Cir. 1963).

97. Cf., Kurland, Toward a Co-operative Judicial Federalism: The Federal Court Abstention Doctrine, 24 F.R.D. 481 (1960); Note, 73 HARv. L. REv. 1358, 1368-69 (1960) ; Note, 111 U. PA. L. REv. 344, passim (1963). 
most readily by state legislation. The most satisfactory solution, undoubtedly, lies in uniform legislation, which might be closely modeled after the Florida statute, ${ }^{98}$ even though in some jurisdictions some constitutional changes may be required to effectuate the provision for certification.99 Perhaps in some jurisdictions the necessary procedure could be attained by less drastic changes - for example, modification of existing declaratory judgment processes to enable litigants referred to state courts under the abstention doctrine to bypass lower courts. If some states fear placing too great a burden upon their courts, ${ }^{100}$ these fears would likely be stilled by development of a spirit of cooperation between the two judicial systems, and a wise and seasoned use of the certification device by the federal courts. In any event, state establishment of the procedure seems preferable to federal imposition of it, which might not be completely effective. ${ }^{101} \mathrm{Mr}$. Justice Douglas wrote in his separate opinion in England v. Louisiana State Bd. of Medical Examiners:"102 "We cannot require the States to provide ... a [certification] procedure ...,"103 indicating some doubt of the Supreme Court's power to compel the state courts to answer certificates. While it might be thought that Congress, if not the Court, could require such reception by the states, the case law is far from persuasive. In Testa v. Katt, ${ }^{104}$ a federal statute required state courts to entertain suits under the Emergency Price Control Act; a Rhode Island state court had refused to hear a cause brought under the act. The Supreme Court said that the state court was not entitled so to refuse jurisdiction, since the questions posed could be decided and the remedies afforded could be given within the framework of judicial machinery presently existing in the state. Certification is a very different matter, for it may require an entirely new procedural framework within a given state. ${ }^{108}$ It may raise serious problems under local "case and controversy" requirements or exorcise a state's distaste for advisory opinions. ${ }^{106}$ Even if the Congress could force such a procedure upon the state courts, it seems politically more desirable for the state independently to adopt the necessary constitutional and statutory provisions.

\section{Conclusion}

Resolution of the broad questions raised by the Fifth Circuit's expansive use of the abstention doctrine in diversity suits, requiring as it does essentially

98. Such a statute has been proposed in a student note. See Note, 111 U. PA. L. REv. 344,363 (1963).

99. See Note, 111 U. PA. L. REv. 344, 351-57 (1963).

100. See note 90 supra (Letter from Hon. Fred M. Burns).

101. Kurland, Mr. Justice Frankfurter, The Supreme Court and the Erie Doctrine in Diversity Cases, 67 YaLe L.J. 187, 214 (1957). See HART \& WeCHSLER 395-99; Note, 73 HARv. L. REv. 1358, 1368 (1960).

102. 375 U.S. 411 (1964).

103. Id. at 434 (emphasis added).

104. 330 U.S. 386 (1947). See sources cited note 101 supra.

105. States having intra-jurisdictional certification procedures and/or advisory opinion procedures might not succeed in this argument.

106. See, e.g., Note, 40 Texas L. Rev. 1041 (1962). Cf. CahN, The Moral Decision 
political judgments as to the role of courts under federalism, is perhaps better left to Congress than to the courts. ${ }^{107}$ If the diversity jurisdiction is to be renounced or substantially altered, the judgment seems best made through legislative channels. To the extent earlier abstention cases presented these problems of federalism, the same conclusion suggests itself. Significantly, however, in those cases there was a previously articulated congressional policy which may have resolved any questions of federalism. ${ }^{108}$ Moreover, the abstention sanctioned there encompassed only a very limited segment of the total jurisdictional spectrum. An extension of the magnitude forecast by Green and Delaney would substantially affect the federal jurisdiction and would run counter to a consistent and long established congressional policy to preserve, undiluted, the diversity of citizenship jurisdiction. ${ }^{109}$ If an apology is needed for judicial usurpation in the earlier cases, it can perhaps be dismissed as de minimis; the potential usurpation in Green and Delaney cannot be excused as lightly. If the courts are going to continue to act in this area, a decision with the potential impact of Green is certainly deserving of more than an unreasoned and unsupported opinion such as accompanied that case. If inquiry into the problems of federalism that bear upon the decision of whether or not to abstain persuade against abstention in cases such as Green and Delaney, it does not seem that the mere availability of a certification statute would justify abstention. ${ }^{110}$ In the absence of considerations of federalism to support abstention, the inevitable added costs of litigation suggest that use of the doctrine is inappropriate. Where the threshold questions of federalism suggest that abstention may be appropriate, an assessment of these costs is still essential. If the methods available for implementation of abstention involve substantial delay or expense, or threaten complete loss of the federal forum, the benefits flowing from use of the doctrine seem to be too speculative to justify its use. Declaratory judgment proceedings seem to pose such a threat. Certification is, by no means, a perfect device, but it may be that it so mitigates the difficulties to litigants that the threat would be found tolerable.

19 (1955).

107. Cf. M. H. Cardozo, Choosing and Declaring State Laze: Deference to State Courts Versus Federal Responsibility, 55 Nw. U.L. Rev. 419, 426 (1960).

108. See notes 53-61 supra and accompanying text.

109. See note 44 supra.

110. The Court indicates that perhaps it has adopted a contrary attitude. The disposition by unreasoned per curiam orders of two cases at the current term in which certification was ordered suggests this attitude. See Dresner v. City of Tallahassee, 375 U.S. 136 (1963) ; Aldrich v. Aldrich, 375 U.S. 75 and 249 (1963). See also the separate opinion of Mr. Justice Douglas in England v. Louisiana State Bd. of Medical Examiners, 375 U.S. 411, 433-34 (1964). 